\title{
Establishment of Honey Mesquite and Huis- ache on a Native Pasture
}

\author{
R.E. MEYER AND R.W. BOVEY
}

\section{Abstract}

Scarifled honey mesquite [Prosopis julflora (Swartz) DC. var. glandulosa (Torr.) Cockerell] and huisache [Acacia farnesiana(L.) Willd.] seeds were broadcast on a native pasture to study their ability to establish plants under several mechanical and chemical treatments. Plots were subjected to mowing, disking, or herbicide treatments. After 5 years, no more than 1 and $2 \%$ of the original honey mesquite and huisache seeds ultimately produced established plants. However, no treatment entirely prevented the establishment of either species. During the 3- to 5-year period following seeding, honey mesquite plant numbers increased with close mowing ( 3 to $5 \mathrm{~cm}$ high) and high mowing (25 to $30 \mathrm{~cm}$ high) without fertilization. Huisache plant numbers increased most prominently on the untreated plots, on plots mowed close and high but without fertilizer, and on plots sprayed with a $1.1 \mathrm{~kg} / \mathrm{ha}$ of $2,4-\mathrm{D}[(2,4-$ dichlorophenoxy)acetic acid] the year of seeding. Overall, the most effective treatment for controlling both species was $1.1 \mathrm{~kg} / \mathrm{ha}$ of picloram (4-amino-3,5,6-trichloropicolinic acid) applied during the fall following seeding in the spring. Neither the trentments nor the brush cover affected herbaceous vegetative cover or estimated herbage yield during the 3- to 5-year period following seeding.

Honey mesquite [Prosopis juliflora (Swartz) DC. var. glandulosa (Torr.) Cockerell] and huisache [Acacia farnesiana (L.) Willd.] infest about 22.7 and 1.0 million hectares, respectively, of rangeland in Texas (Smith and Rechenthin 1964). Honey mesquite can be controlled by broadcast foliar sprays containing 2,4,5-T (Beck et al. 1975a,b; Boyd et al. 1978; Fisher et al. 1972) and to a lesser extent by herbicides applied subsurface to the soil (Meyer and Bovey 1979). Huisache can be controlled either by foliar applications of picloram or picloram $+2,4,5-\mathrm{T}$ (Bovey et al. 1969) or by soil surface of subsurface applications of tebuthiuron $\{N-[5-(1,1-$ dimethylethyl)-1,3,4-thiadiazol-2-yl]-N,N-dimethylurea\} (Bovey and Meyer 1978). These species can also be controlled at least partially by basal oiling, grubbing, chaining, mowing, rootplowing, or fire (Boyd et al. 1978, Fisher et al. 1959, Weddle and Wright 1970, Wiedemann et al. 1977, Wright et al. 1976).

These troublesome species are spread by seed carried primarily in the digestive tract of animals and subsequently excreted uninjured on the soil surface. Seeds of both species have a hard, impervious seed coat; germination occurs only sporadically until the seeds are scarified either mechanically or chemically, generally either by natural forces or by passing through the digestive tract of animals (Fisher et al. 1959).

Honey mesquite germinates and produces more vigorous seedings at $29^{\circ} \mathrm{C}$ than at 21 or $38^{\circ} \mathrm{C}$ (Scifres and Brock 1969). Seedlings can emerge and survive in continuous $50 \%$ reduction in radiant energy from full sunlight, but they cannot survive in over $90 \%$ reduction in radiant energy (Scifres et al. 1973). Maximum seedling emergence occurred when the seeds were planted $0.5 \mathrm{~cm}$ deep at $27^{\circ} \mathrm{C}$ soil temperature (Scifres and Brock 1972). Seeds

\footnotetext{
The authors are plant physiologist and research agronomist, Agr. Res. Serv. U.S Dep. Agr., Department of Range Science, Texas A\&M University, College Station 77843.

Cooperative investigation of Agr. Res. Serv., U.S. Dep. Agr., and the Texas Agr. Exp. Sta., Texas A\&M University.

Manuscript received October 9, 1980.
}

placed on the soil surface germinated, but the seedlings did not survive. Seeds planted 5 to $6 \mathrm{~cm}$ deep germinated but failed to emerge.

The honey mesquite radicle usually emerges 12 to $18 \mathrm{hr}$ after planting in a warm, moist environment. A noticeable collar of cortical tissue separates the radicle from the hypocotyl within $48 \mathrm{hr}$ (Meyer et al. 1971, Scifres and Hahn 1971). Generally, the cotyledons are fully expanded, and the epicotyl is prominent by the third or fourth day. The first true leaf above the cotyledons is compound; subsequent leaves are doubly compound. Plants grown in a warm greenhouse are usually 10 to $20 \mathrm{~cm}$ tall after 2 months. Reproduction and establishment of velvet mesquite [Prosopis juliflora var. velutina (Woot.) Sarg.] are similar to that of honey mesquite (Glendening and Paulsen 1955).

Honey mesquite seedlings, regardless of age, fail to survive when the tops are removed below the cotyledonary node (Meyer et al. 1971, Scif res and Hahn 1971). Scifres and Hahn (1971) found that $60 \%$ of 7 -day-old seedlings grown in the greenhouse survived top removal above the cotyledons. Top removal just above the cotyledons resulted in branching from the cotyledonary node. The number of sprouts per seedling increased progressively as the seedlings were allowed to develop up to 56 days after emergence before top removal. Honey mesquite seedlings grown in the greenhouse and field normally have a single stem unless the top is injured or removed above the cotyledonary node.

Scifres (1974) found that more huisache seeds germinated at $30^{\circ} \mathrm{C}$ than at 16,21 , or $38^{\circ} \mathrm{C}$. The seeds were not light-senstive, and optimum seedling emergence occurred when the seeds had been planted $2 \mathrm{~cm}$ deep. Few seedlings became established when the seeds had been left exposed on the soil surface. When planted deeper than $6 \mathrm{~cm}$, huisache seeds germinated but failed to emerge.

Bovey and Meyer (1974) reported that either picloram or 2,4,5-T applied broadcast at $0.28 \mathrm{~kg} /$ ha killed $73 \%$ or more of greenhousegrown honey mesquite seedlings up to 8 weeks after emergence, but the percentage killed declined thereafter. Picloram killed $90 \%$ or more of the huisache up to 8 weeks after emergence; $2,4,5$-T killed only $72 \%$ I week after emergence and killed a significantly fewer plants thereafter.

Few data are available concerning the influence of existing vegetation and the microenvironment on seed germination and seedling growth and survival of honey mesquite and huisache under natural conditions. However, Ueckert et al. (1979) found that competition with associated vegetation overshadowed the effects of soil properties on honey mesquite seedling survival.

This study was undertaken to determine the influence of various herbicide and mechanical practices on the establishment of honey mesquite and huisache from seed on a native pasture.

\section{Materials and Methods}

The study was conducted on a Bleiberville clay (a member of the Thermic Udic Pellusterts) with a 3\% slope near Bryan, Texas, in the Post Oak Savannah resource area. The experimental area had been cultivated about 8 years prior to the establishment of the plots. The area was ungrazed during those 8 years and the 5 -year 


\section{study period.}

Predominate grasses on the site included: broomsedge (Andropogon virginicus L.), johnsongrass [Sorghum halepense (L.) Pers.], King Ranch bluestem [Bothriochloa ischaemum (L.) Keng. var. songarica (Rupr.) Celerier \& Harlan], longspike silver bluestem [Bothriochloa saccharoides var. longipaniculata (Gould) Gould], and purple threeawn (Aristida purpurea Nutt.). Principal broadleaf species included western ragweed (Ambrosia psilostachya DC.) with scattered plants of lemon beebalm (Monardo citriodora Cerv.), saw greenbrier (Smilax bona-nox L.), southern dewberry (Rubus trivialis Michx.), and threadleaf groundsel (Senecio longilobus Benth.).

Twenty-four plots, 21 by $38 \mathrm{~m}$, were established with mowed buffer zones $6 \mathrm{~m}$ wide between them. Eight treatments with three replicates each were arranged in a randomized, complete block design.

Approximately 6,000 scarified seeds each of honey mesquite $(226 \mathrm{~g})$ and huisache $(357 \mathrm{~g})$ were distributed evenly by hand over each plot at the beginning of the study on March 14, 1974. Before dispersal, honey mesquite seeds had been mechanically scarified by a process described by Flynt and Morton (1969), and huisache had been chemically scarified by soaking for 45 minutes in concentrated sulfuric acid (Bovey et al. 1979).

The close mowing plots were shredded to a stubble height of 3 to $5 \mathrm{~cm}$ to simulate heavy grazing. High mowing plots were shredded 25 to $30 \mathrm{~cm}$ high to simulate moderate herbage use. The third treatment consisted of an application of 12-12-12 fertilizer at 280 $\mathrm{kg} / \mathrm{ha}$ followed by mowing at a height of 25 to $30 \mathrm{~cm}$. During 1974 through 1977, plots were mowed in May, July, and October. No mowing was done in 1978 or 1979 in order to allow the woody plants to grow large enough to be visible for counts and to allow sufficient growth of herbaceous plants for composition and yield measurements.

A fourth treatment consisted of disking the soil $15 \mathrm{~cm}$ deep and harrowing to form a good seed bed. The honey mesquite and huisache seeds were sown on the soil surface, but not subsequently covered with soil.

Three broadcast herbicide spray treatments were established. Tebuthiuron ( $80 \%$ wettable powder) and the propylene glycol butyl ether esters of 2,4-D were applied on May 6, 1974. The potassium salt of picloram was applied October 7, 1974. All herbicides were applied at $1.1 \mathrm{~kg} / \mathrm{ha}$ in water equivalent to $187 \mathrm{~L} / \mathrm{ha}$ with a tractor-mounted boom sprayer. No additional herbicide applications were made. The eighth set of plots was left untreated.

Honey mesquite and huisache plants were counted in each plot on June 1, 26, and 22 in 1977, 1978, and 1979, respectively. Percent canopy cover of each herbaceous species was estimated visually for each plot on June 1, 1977, and June 22, 1979. Herbage production was estimated October 27,1978 by harvesting all herbaceous vegetation mowed to a stubble height of about $4 \mathrm{~cm}$ from two areas 1 by $3 \mathrm{~m}$ near the center of each plot. Herbage was separated into grasslike plants and broadleaf plants and oven-dried at $70^{\circ} \mathrm{C}$. Herbage yield is expressed on an oven-dry-weight basis.

\section{Results and Discussion}

In 1979, untreated honey mesquite and huisache averaged 1.2 and $2.5 \mathrm{~m}$ tall, respectively. Within a treatment, at least in 1978 and 1979, more huisache than honey mesquite became established, except for the picloram spray treatment where no appreciable difference occurred (Table 1). Seedlings of huisache were more able than honey mesquite to become established even under the competition from existing herbaceous vegetation and attack by rabbits which nipped the tops of both species during the seedling stage. Regardless of treatment, however, both woody species were able to compete with the herbaceous vegetation and become established. Consequently, it does not seem possible to exclude the establishment of either honey mesquite or huisache in a native pasture containing viable seeds even without grazing, mowing, or other forage use. Herbicides and probably prescribed burning on a regular basis would control young woody plants better than the competitive effect of existing vegetation.

The number of huisache plants tended to increase more during the study than honey mesquite (Table 1). Huisache plant numbers continued to increase most prominently in plots mowed close, mowed high without fertilizer, sprayed with 2,4-D, and left untreated. Honey mesquite plant numbers only increased with close mowing and high mowing without fertilizer. Apparently, as is found in greenhouse experiment, a higher percentage of scarified honey mesquite germinates immediately than does huisache. Progressive seed germination over a 5-year period would make huisache more likely to have some seedlings become established than honey mesquite which germinates only over a 1 - to 3-year period. Also, the growth rate of huisache seedlings is greater than that of honey mesquite.

The two species responded similarly regarding plant numbers to the various treatments (Table 1). In 1977, the most honey mesquite plants occurred on plots receiving disking and high mowing, with or without fertilizer. The fewest plants were present on the untreated plots and on areas receiving close mowing and 2,4-D or picloram sprays. In subsequent years, treatment differences decreased so that the only significant difference in honey mesquite establishment was between high mowing without fertilizer and the picloram treatment.

In 1977, huisache seedling establishment was greatest on untreated plots and on those receiving disking and high mowing, particularly with fertilizer. In 1978, the only significant difference occurred between high mowing with fertilizer and the picloram spray. In 1979, fewer huisache plants were present in the plots treated with picloram than either the untreated or those receiving high or close mowing.

Thus, picloram at $1.1 \mathrm{~kg} /$ ha during the fall after spring seeding

Table 1. Honey mesquite and huisache plant numbers on plots 21 by $38 \mathrm{~m}$ on which 6,000 seeds had been broadcast March 14, 1974, and were counted in June 3,4 , and 5 years later.

\begin{tabular}{|c|c|c|c|c|c|c|}
\hline \multirow[b]{3}{*}{ Treatment } & \multicolumn{6}{|c|}{ Seedlings (number per plot)' } \\
\hline & \multicolumn{3}{|c|}{ Honey mesquite } & \multicolumn{3}{|c|}{ Huisache } \\
\hline & 1977 & 1978 & 1979 & 1977 & 1978 & 1979 \\
\hline $\begin{array}{l}\text { 1. Close mowing } \\
\text { 2. High mowing } \\
\text { 3. Fertilizer }+ \text { high mowing } \\
\text { 4. Disking } \\
\text { 5. } 2,4-D \text { at } 1.1 \mathrm{~kg} / \mathrm{ha} \\
\text { 6. Picloram at } 1.1 \mathrm{~kg} / \mathrm{ha} \\
\text { 7. Tebuthiuron at } 1.1 \mathrm{~kg} / \mathrm{ha} \\
\text { 8. Untreated } \\
\quad \text { Mean }\end{array}$ & $\begin{array}{l}8 \mathrm{~d} \\
31 \mathrm{ab} \\
40 \mathrm{a} \\
31 \mathrm{ab} \\
11 \mathrm{~d} \\
3 \mathrm{~d} \\
24 \mathrm{bc} \\
14 \mathrm{~cd} \\
20\end{array}$ & $\begin{array}{l}42 \mathrm{ab} \\
47 \mathrm{a} \\
30 \mathrm{ab} \\
36 \mathrm{ab} \\
14 \mathrm{ab} \\
9 \mathrm{~b} \\
16 \mathrm{ab} \\
16 \mathrm{ab} \\
26\end{array}$ & $\begin{array}{l}56 \mathrm{ab} \\
74 \mathrm{a} \\
34 \mathrm{ab} \\
39 \mathrm{ab} \\
24 \mathrm{ab} \\
7 \mathrm{~b} \\
29 \mathrm{ab} \\
22 \mathrm{ab} \\
36\end{array}$ & $\begin{array}{l}15 c d \\
46 a-d \\
85 a \\
50 a-c \\
11 c d \\
6 d \\
30 b-d \\
65 a b \\
38\end{array}$ & $\begin{array}{l}60 \mathrm{ab} \\
72 \mathrm{ab} \\
78 \mathrm{a} \\
54 \mathrm{ab} \\
31 \mathrm{ab} \\
6 \mathrm{~b} \\
28 \mathrm{ab} \\
58 \mathrm{ab} \\
48\end{array}$ & $\begin{array}{l}114 \mathrm{a} \\
119 \mathrm{a} \\
94 \mathrm{a} \\
86 \mathrm{ab} \\
57 \mathrm{ab} \\
12 \mathrm{~b} \\
50 \mathrm{ab} \\
105 \mathrm{a} \\
80\end{array}$ \\
\hline
\end{tabular}

IValues in columns followed by the same letter are not significantly different at the $5 \%$ level using the Duncan multiple range test. 
was the most effective treatment overall for limiting the establishment either of honey mesquite or huisache. This is not surprising since picloram is one of the most effective herbicides known for the control of these two species. However, no more than 1 and $2 \%$ of the honey mesquite and huisache seeds, respectively, had germinated and established plants by 5 years after seeding.

Herbaceous cover was estimated in June of 1977 and 1979. No significant differences in cover values were detected among treatments for either year. In 1977, foliar covers of total grass, perennial grass, a nnual grass, and total broad leaf plants (data for treatments not shown) were $87,50,37$, and $7 \%$, respectively for all treatments; in 1979 , the same vegetation categories were $81,76,5$, and $14 \%$, respectively. Johnsongrass composed 29 and $18 \%$ of the perennial grass cover in 1977 and 1979, respectively. The largest vegetation difference between 1977 and 1979 was the increase in perennial grasses other than johnsongrass and the decrease in annual grasses in 1979. Likewise, in 1978, there were no significant differences among treatments in herbaceous standing crop (data not shown). The mean total vegetation, grass, and broadleaf oven-dry standing crop were $2,3782,336$, and $42 \mathrm{~kg} / \mathrm{ha}$, respectively, averaged across all treatments. Thus, 3 to 5 years after planting, neither the treatments imposed nor the infestations of honey mesquite or huisache had a significant influence on either herbaceous cover or estimated herbage yield.

Although no more than $2 \%$ of the seeds planted produced established plants 5 years after treatment, none of the treatments entirely prevented the establishment of some plants. A broadcast spray of picloram at $1.1 \mathrm{~kg} / \mathrm{ha}$ during the fall of the year of seeding gave the best control of both woody species. Thus, competition from native herbaceous plants alone will not prevent the invasion of either honey mesquite or huisache in the Post Oak Savannah resource area of Texas.

\section{Literature Cited}

Beck, D.L., R.E. Sosebee, and E.B. Herndon. 1975a. Chemical control of mesquite regrowth of different ages. J. Range Manage. 28:408-410.

Beck, D.L., R.E. Sosebee, and E.B. Herndon. 1975b. Control of honey mesquite by shredding and spraying. J. Range Manage. 28:487-490.

Bovey, R.W., J.R. Baur, and H.L. Morton. 1969. Control of huisache and associated woody species in south Texas. J. Range Manage. 23:47-50.

Bovey, R.W., and R.E. Meyer. 1978. Control of huisache with soil-applied herbicides. J. Range Manage. 31:179-182.
Bovey, R.W., and R.E. Meyer. 1974. Mortality of honey mesquite and huisache seedlings from herbicides and top removal. Weed Sci. 22:276279.

Bovey, R.W., R.E. Meyer, and H.L. Morton. 1979. The use of a woody plant nursery in herbicide research. Tex. Agr. Exp. Sta. Bull. 1216. 80 p.

Boyd, W.E., R.E. Sosebee, and E.B. Herndon. 1978. Shredding and spraying honey mesquite. J. Range Manage. 31:230-233.

Fisher, C.E., C.H. Meadors, R. Behrens, E.D. Robison, P.T. Marion, and H.L. Morton. 1959. Control of mesquite on grazing lands. Tex. Agr. Exp. Sta. Bull. 935.24 p.

Fisher, C.E., H.T. Wiedemann, J.P. Walter, C.H. Meadors, J.H. Brock, and B.T. Cross. 1972. Brush control research on rangeland. Tex. Agr. Exp. Sta. Misc. Pub. 1043. 18 p.

Flynt, T.O., and H.L. Morton. 1969. A device for threshing mesquite seed. Weed Sci. 17:302-303.

Glendening, G.E., and H.A. Paulsen. 1955. Reproduction and establishment of velvet mesquite as related to invasion of semidesert grasslands. U.S. Dep. Agr. Tech. Bull. 1127. 50 p.

Meyer, R.E., and R.W. Bovey. 1979. Control of honey mesquite (Prosopis juliflora var. glandulosa) and Macartncy Rose (Rosa bracteata) with soil-applied herbicides. Weed Sci. 27:280-284.

Meyer, R.E., H.L. Morton, R.H. Haas, E.D. Robison, and T.E. Riley. 1971. Morphology and anatomy of honey mesquite. U.S. Dep. Agr. Tech. Bull. 1423. 186 p.

Seifres, C.J. 1974. Salient aspects of huisache seed germination. Southwestern Naturalist 18:383-392.

Scifres, C.J., and J.H. Brock. 1972. Emergence of honey mesquite seedlings relative to planting depth and soil temperature. J. Range Manage. 25:217-219.

Scifres, C.J., and J.H. Brock. 1969. Moisture-temperature interrelations in germination and early seedling development of mesquite. J. Range Manage. 22:334-337.

Scifres, C.J., and R.R. Hahn. 1971. Response of honey mesquite seedlings to top removal. J. Range Manage. 24:296-298.

Scifres, C.H., C.R. Kienast, and D.J. Elrod. 1973. Honey mesquite seedling growth and 2,4,5-T susceptibility as influenced by shading. J. Range Manage. 26:58-60.

Smith, H.N., and C.A. Rechenthin. 1964. Grassland restoration. Part I. The Texas brush problem. U.S. Dep. Agr. Soil Conserv. Serv. Bull. 4-19114. $17 \mathrm{p}$.

Ueckert, D.N., L.S. Smith, and B.L. Allen. 1979. Emergence and survival of honey mesquite seedlings on several soils in west Texas. J. Range Manage. 32:284-287.

Weddle, J.P., and H.A. Wright. 1970. An evaluation of five methods to retreat sprayed mesquite. J. Range Manage. 23:411-414.

Wiedemann, H.T., B.T. Cross, and C.E. Fisher. 1977. Low-energy grubber for controlling brush. Trans. Amer. Soc. Agr. Engineers 20:210-213.

Wright, H.A., S.C. Bunting, and L.F. Neuenschwander. 1976. Effect of fire on honey mesquite. J. Range Manage. 29:467-471. 